UDC 579.864.637.146

\author{
Elene Kakabadze ${ }^{1,2}$, Nata Bakuradze ${ }^{1,2}$, Nino Grdzelishvili², \\ Khatuna Makalatia ${ }^{1,2}$, Gulnara Natroshvili ${ }^{2}$, Nina Chanishvili ${ }^{2}$ \\ ${ }^{1}$ Ivane Javakhishvili Tbilisi State University, Faculty of Exact and Natural Science, \\ 1, Chavchavdze Ave., 0179 Tbilisi, Georgia \\ ${ }^{2} \mathrm{G}$. Eliava Institute of Bacteriophage, Microbiology and Virology, \\ 3, Gotua str., Tbilisi, 0160, Georgia \\ tel.: +995322374910 e-mail: elene.kakabadze@pha.ge
}

\title{
MICROBIOLOGICAL INVESTIGATION OF ARTISANAL CAUCASIAN YOGURT-LIKE PRODUCT MATSONI
}

\begin{abstract}
Aim. To investigate microbial composition of the home-made Matsoni samples and select the bacterial cultures for further development of the standardized starter(s), challenging modern biotechnological requirements. Methods. Strain isolation and purification, culture evaluation for their catalase and urease activities, casein fermentation, galactose degradation ability, exopolysaccharide (EPS) and bacteriocin production, and lysogeny. Results. One hundred forty four lactic acid bacterial cultures were isolated from thirty five homemade Matsoni samples, collected from twenty four different settlements in Georgia during years 2013-2014. Bacterial structure of the starters showed great diversity in their composition, 3\% of isolates showed casein degradation and EPS production potential, 32\% were positive for galactose fermentation, 19\% showed urease activity, 17\% revealed antagonistic properties and 14\% were denoted as lysogenic. Conclusions. The developed strain collection shows potential to provide various organoleptic properties to the end products and, thus, after molecular characterization, can be easily used for construction of new standardized Matsoni starters.
\end{abstract}

Key words: Lactic acid bacteria, Matsoni, Starter strain, Biotechnology.

Lactic acid bacteria (LAB) is the most important and useful functional group of phylogenetically related bacteria used in dairy industry. Belonging to the order of Lactobacillales, phylum Firmicutes, vast variety of the LAB strains are granted the status of 'generally recognized as safe' (GRAS), meaning they can be applied as food additives or supplements and are commonly used in yogurt, hard chesses, kefir, cultured butter, cottage cheese and sour cream production. Due to LAB metabolic activity, fermented milk products acquire different organoleptic characteristics, hydrolysed proteins, additional vitamins and beneficial lactate, instead of the complex lactose, which may cause digestive problems [7].

The GRAS cultures have to comply to the number of biotechnological characteristics required for the starter strains, including: cultivability, rapid acidification and clot formation in milk, EPS production, phage resistance, galactose fermentation, non-antagonistic activity and enzymatic hydrolysis of casein. The strains that are lysogenic, urease positive and form biogenic amides are not desirable for manufacturing applications.

(C) Елена Какабадзе, Ната Бакурадзе, Ніно Грдзелишвілі, Хатуна Макалатія, Гульнара Натрошвілі, Ніна Чанішвілі, 2018 
In the industrial fermentation process the majority of the used LAB strains do not utilize galactose moiety of lactose and proceed only with glucose fermentation. Accumulation of galactose in the final product, may lead to domination of undesirable microflora and accumulation of toxic galactitol in the consumer's body. Thereby, the phenotypes expressing Leloir pathway, which dissimilate galactose to Glucose$1-\mathrm{P}$ are in demand [14].

The LAB produce broad range of extracellular saccharides, which can have extended industrial application. The EPS are not permanently attached to the producer cell surface and can be easily harvested. Evolutionary EPS carry protective functions against bacteriophages and may enhance adhesion capability of microbe. In yogurt-like products the EPS production influences clot consistence, making it more firm and stabile. The EPS production and yield highly depends not only on the strain phenotype, but also on the growth conditions and supplements. Usage of higher concentration of several carbohydrates in the growth media enhances overall EPS production of different LAB strains. At the same time sugar enhanced EPS production is strain specific, a distinguished carbohydrate or combination of sugars have to be estimated for each individual strain [13].

The LAB strains may produce variety of different antagonistic agents, that may interfere with fermentation process, such as: bacteriocins, benzoic acid, biogenic amines, high concentration of lactic acid or hydrogen peroxide. In particular bacteriocins, the short peptide chains that carry antibiotic like properties, may have specific actions against food borne pathogens or undesirable flora. Therefore, bacteriocin producing cultures gain increasing interest as probiotic vectors. For example, nisin - the type A lantibiotic, produced by Lactococcus lactis ssp. lactis is well characterized bacteriocin, that is extensively used as natural food preservative [5].

Urease activity is one of the undesirable characteristics of starter cultures related to $S$. thermophilus. Enzymatic hydrolysis of urea (if presented in milk in average $0.2-0.4 \mathrm{~g} \mathrm{l}^{-1}$ ) not only significantly slows down the acidification process, but may also have a toxic effect, due to accumulation of $\mathrm{NH} 3$ in the final product [10].

The starter strains may be susceptible to phages that are present in manufacturing environment, or undergo induction during fermentation process in case of lysogenic starter strains that carry temperate bacteriophages (prophages) in their genome. Phage-bacteria interaction or activation of prophage may occur at any time, temperate phages may switch to lytic cycle, start multiplying and cause burst of the host cell, spreading infection to the whole batch. Phage outbreaks can cause serious financial and quality damage to the manufacturing process, even a delay of production for many months [2]. Therefore, the strains should be tested on prophage induction and phage resistance before potential manufacturing use.

In industry of yogurt-like products Lactobacillus ssp. bulgaricus and Streptococcus thermophilus cultures are generally utilized for manufacturing of stirred or drinking yogurt. For instance, traditional starter set for Balkan yogurt is composed of L. delbrueckii ssp. bulgaricus and S. thermophilus, (2.5-6 h long fermentation); for mild yogurt preparation protosymbiotic, thermophilic cultures of L. acidophilus and $S$. thermophiles (6-7 h fermentation) are used. Probiotic yogurt- 
like products usually contain strains of $L$. acidophilus, L. johnsonii, L. casei, $L$. rhamnosus, L. gasseri, L. reuteri, along with Bifidobacterium bifidum, B. longum, and B. infantis [9].

From the vast variety of traditional dairy foods produced in Georgia, Matsoni has a special place in everyday diet of the local population, especially in child nutrition. Matosni is white, smooth, semi-liquid, yogurt like fermented product, common in every part of the country. It can be made from cow, buffalo, sheep and goat milk, or their mixtures. Products final acidity ranges around $70-150^{\circ} \mathrm{T}$. Overall, the microbial ecosystem of Matsoni is considered to be largely dominated by the thermophilic species: S. thermophilus and L. delbrueckii. High density of LAB other than these two species, including L. helveticus, L. paracasei and Leuconostoc lactis, were found to occur as well [11].

At present all Georgian traditional products including yogurt-like product Matsoni actually are made using the replacement cultures imported from different counties. The products manufactured using these starters resembles Matsoni, but still there are great differences in texture, flavour and taste in comparison with the traditional Georgian product.

Due to peculiarity of the preparation method, based on back-sloping, uncontrolled usage and marketing of imported starter cultures, strains migrate from commercial products to home-made batches, replacing established semispontaneous mother cultures. Thus, preserving natural starter composition of traditional Matsoni is of a great importance.

As a measure directed to preservation of the tradition the artisanal method for preparation of Matsoni was adapted and published by Georgian patent agency (Table 1) [15].

Table 1

Standard manufacturing protocol of Matsoni according to Saqpatenti [15]

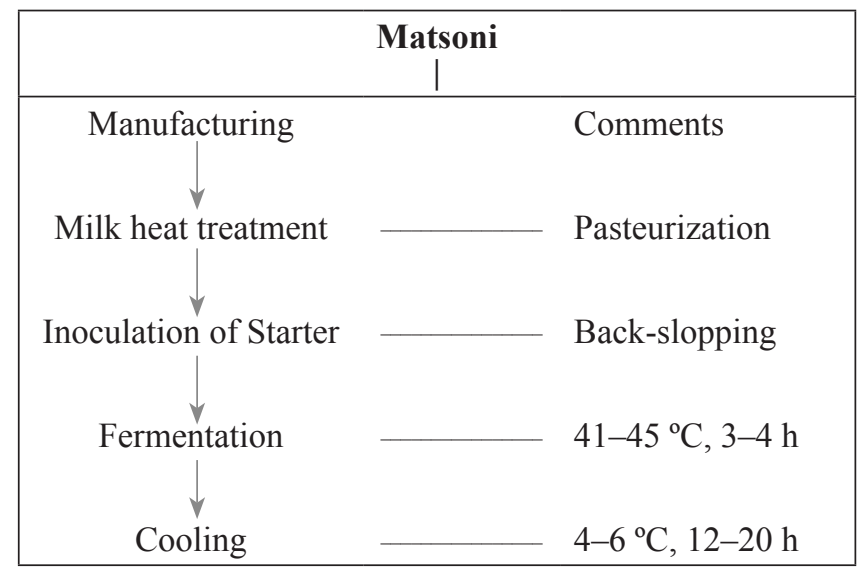

The present study focuses on determination of microbial composition of the home-made Matsoni samples, selection of the bacterial cultures with distinguished biotechnological potential for further molecular investigation and development of the standardized starter(s) for the traditional Caucasian dairy product(s). 


\section{Materials and methods}

Fresh home-made Matsoni samples were collected from twenty four different points in Georgia during 2013-2014 (Picture 1). The samples were immediately transferred to the research laboratory in cooler boxes. $10 \mathrm{ml}$ of sample was taken aseptically from Matsoni jars for further investigation. For obtaining diversity of viable and cultivable, acidifying and lactose-fermenting LABs, the strain isolation was performed according to the method described by D. Carminati at al. (2014) [3].

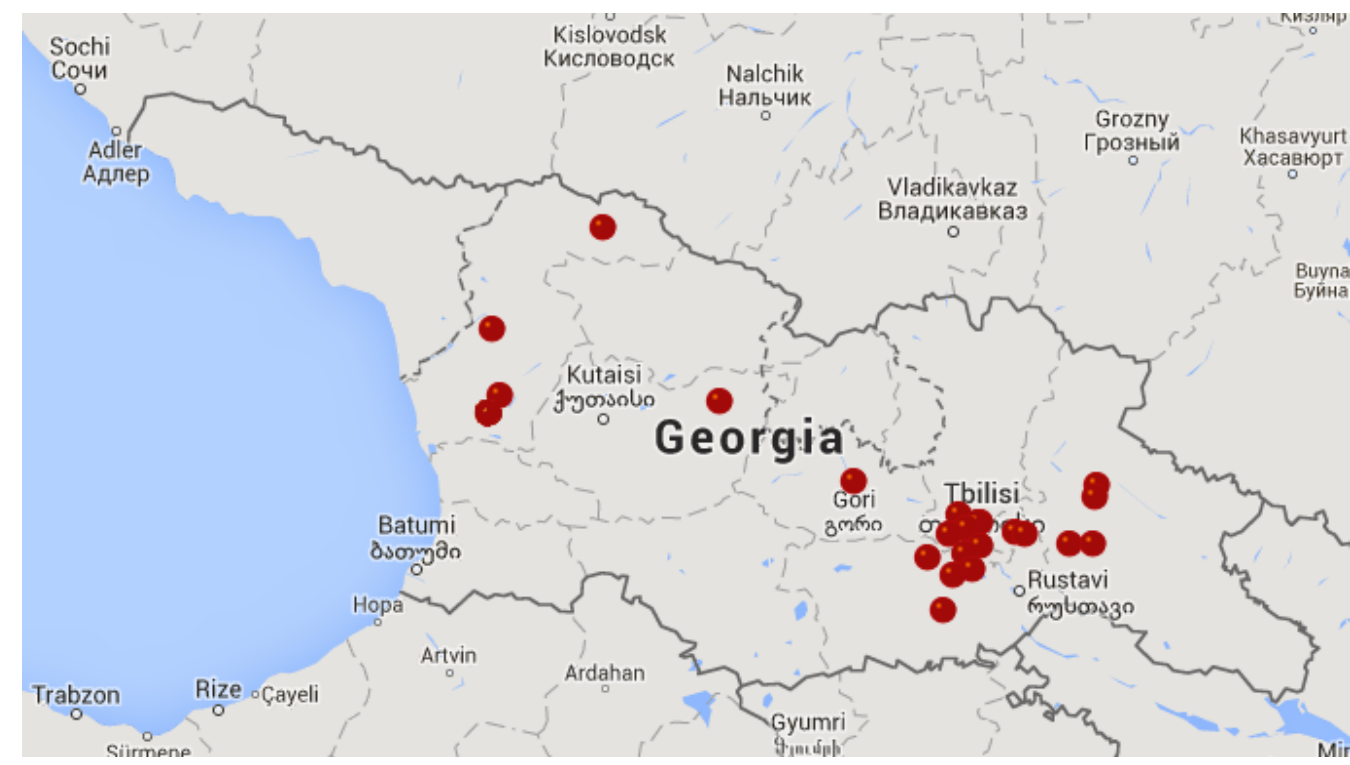

Picture 1. Pinpoints of the sample collection sites in Georgia

Morphologically different colonies were isolated and purified by streaking on the respective solid media (MRS, M17, Bile Esculin Azide Agar). The obtained pure colonies were checked for catalase activity by applying 3\% hydrogen peroxide on the strain colony, Gram staining was performed using the differential staining kit (Deltalab) according to manufacturer's instructions, after which the samples underwent light microscopy (X1000) for morphological classification. After purification the stocks were stored at $-80{ }^{\circ} \mathrm{C}$ with $20 \%$ glycerol. Prior to use the strains were cultivated twice in appropriate liquid media.

Galactose fermentation test was carried out on BSM medium, with phenol red (final concentration of $2 \% \mathrm{w} / \mathrm{v}$ ) and filter sterilized D- $(+)$ Galactose $-0.2 \%$ (w/v) as described by De Man et al (1960) [4].

The $\mathrm{LAB}$ isolates were tested for the ability to digest casein using standard skim milk agar plate method.

Study of lysogeny was performed via spot test and induction of prophages using Mitomycin C, as described by Ra'l, R. Raya and Elvira M. H'bert (2009) [12].

Ability of the EPS production was evaluated in presence of carbohydrate composition (5.26 5.1 lactose $\mathrm{g} / 100 \mathrm{~g}$ ) of normal milk to model the strain behavior 
at manufacturing conditions, according to the method described by Ruas-Madiedo, P. and De Los Reyes-Gavilán, C. G. (2005) [13]

Urease activity test was performed as follows: a pellet was obtained from $2 \mathrm{ml}$ of overnight culture via centrifuging $(10,000 \mathrm{rpm}, 5 \mathrm{~min})$, re-suspended in $2 \mathrm{ml}$ of the indicator solution (yeast extract $-0.1 \mathrm{~g}, \mathrm{KH}_{2} \mathrm{PO}_{4}-9.1 \mathrm{G}, \mathrm{K}_{2} \mathrm{HPO}_{4}-9.5 \mathrm{~g}$, phenol red-0.01g, 1L D.W. pH 6.5, filter sterilized) and incubated for $6-18 \mathrm{~h}$ at $42{ }^{\circ} \mathrm{C}$.

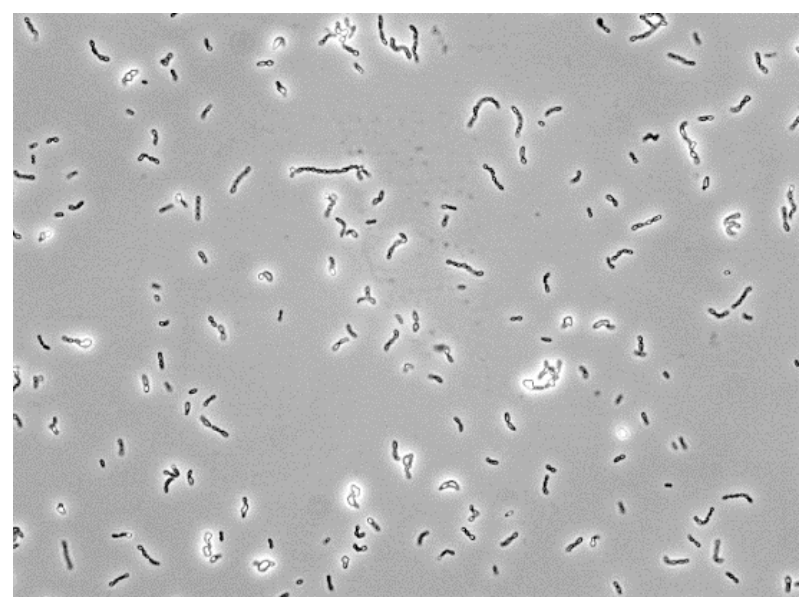

Picture 2. Presumptive Lactobacillus spp. culture, isolated from Matoni sample, Light Microscopy, live culture in MRS medium, magnification 100X

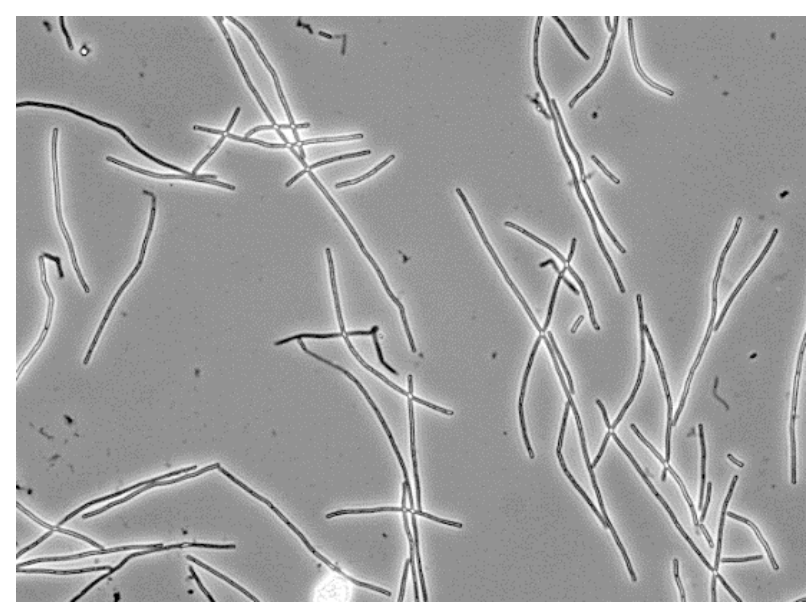

Picture 3. Presumptive Streptococcus thermophilus culture, isolated from Matsoni sample, Light Microscopy, live culture in M17 medium, magnification 100X

Screening of bacteriocin producing strain was performed as follows: overnight cultures were centrifuged at 10,000 rpm for $10 \mathrm{~min}$, supernatant was removed and stored at $-20{ }^{\circ} \mathrm{C}$ until further use. Standard indicator strains: L. plantarum 350 and L. sakei subsp. sakei JCM 1157 (Kindly provided by T. Haertle (FIP, UR1268, Biopolymers Interactions Assemblies, INRA, BP 71627, 44316 Nantes Cedex 3, 
France.) were used as a bacteriocin sensitive lawn. $200 \mu 1$ of log phase indicator strains were mixed with $25 \mathrm{ml}$ of $1 \%$ MRS agar and plated on sterile Petri dish. Plates were allowed to dry and $\varnothing 8 \mathrm{~mm}$ wells were cut and filled with $65 \mu 1$ of the supernatant. After aerobic incubation for $18 \mathrm{~h}$ at $37^{\circ} \mathrm{C}$, the plates were checked for appearance of clear zones. Enterococcus durans A5-11 [1] was used as a positive control. The strains demonstrating positive-reactions were selected for further studies. The selected supernatants were $\mathrm{pH}$ neutralized, hold in water bath for 10 min to exclude high acid production and $\mathrm{H}_{2} \mathrm{O}_{2}$ effects. Additionally the samples were treated with proteinase $\mathrm{K}$ and trypsin $(1 \mathrm{mg} / \mathrm{ml}$ for $90 \mathrm{~min})$ to confirm peptide nature of inhibitory agents.

\section{Results and discussion}

A total of 144 LAB strains were isolated from 35 fresh Matsoni samples. It is important to underline that the majority of the home-made samples contained vast variety of yeast microflora, with average of 4 bacterial isolates per sample, with sample standard deviation of 1.75 , suggesting high variability among different samples. Based on the results obtained using various selective media, temperature conditions, catalase activity tests, Gram profiles and cell morphology eighty two strains were attributed to Lactobacillus spp. four cultures to $S$. thermophilus and fifty eight isolates to Enterococcus spp.

According to the screening results five isolates attributed to Lactobacillus spp. showed ability to degrade casein, which was demonstrated by skim milk agar plate method. Forty six (32\%) out of 144 isolates have been determined as positive for galactose fermentation and five isolates formed mucoid or ropy colonies on Milk agar. Twenty eight isolates (19\%) appeared to be urease positive.

A total of 144 isolates have been tested for lysogeny. Despite the fact that no lysis areas or negative colonies were detected via the spot-test analysis, twenty strains showed decrease of turbidity after induction with Mitomycin C, compared to their controls and, therefore, have to be excluded from the list of the biotechnologically suitable strains.

The isolates have been checked for antagonistic activity against $L$. plantarum 350 and L. sakei subsp. sakei JCM 1157. Two isolates attributed to Lactobacillus spp. and one to Enterococcus spp. showed distinguished antagonistic activity characteristic to bacteriocin production, while twenty one strains showed intergenus antagonistic activity, which is determined by non-peptide factors. Thus, these cultures may not be recommended as potential starter strains, as they may interfere with development of other starter components.

After summarizing the screening results per each isolate according to the characteristics discussed in introduction, sixty five isolates have been validated as suitable candidates as potential starter strains and use for further molecular characterization. 


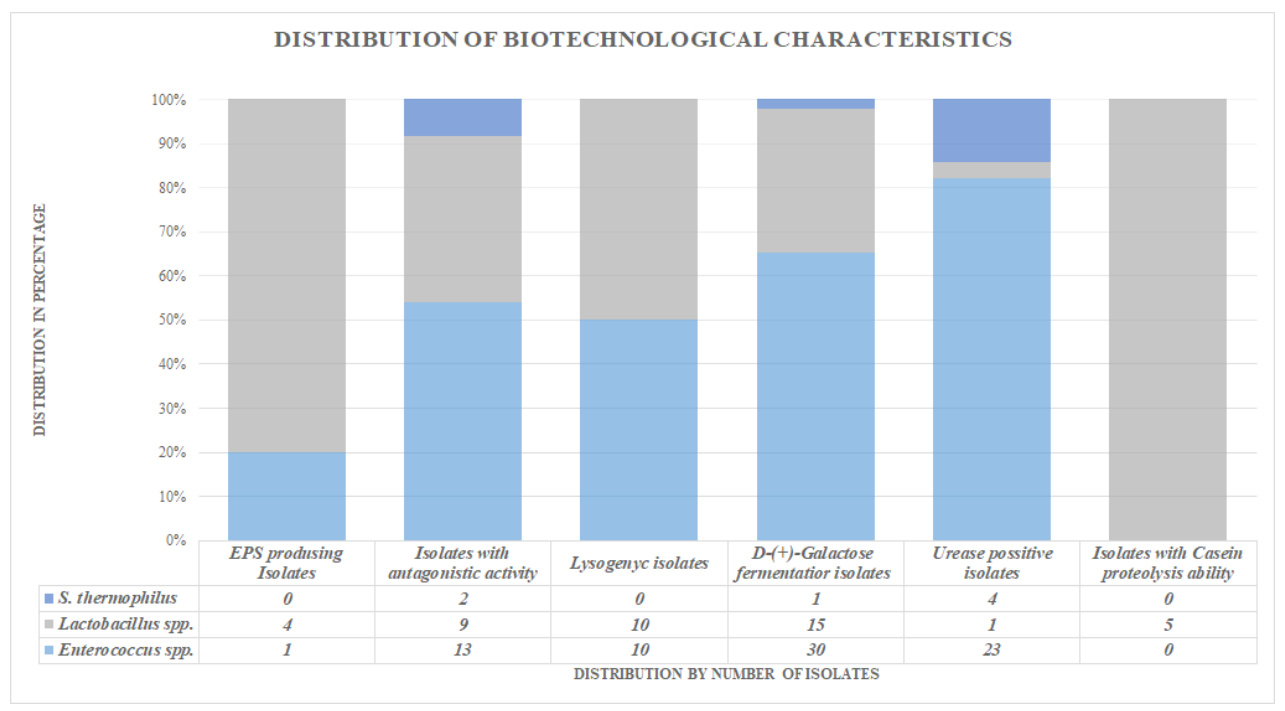

Figure 1. Distribution of different trades of Matsoni isolates

DISTRIBUTION OF VALIDATED ISOLATES FOR FURTHER CHARACTERISATION

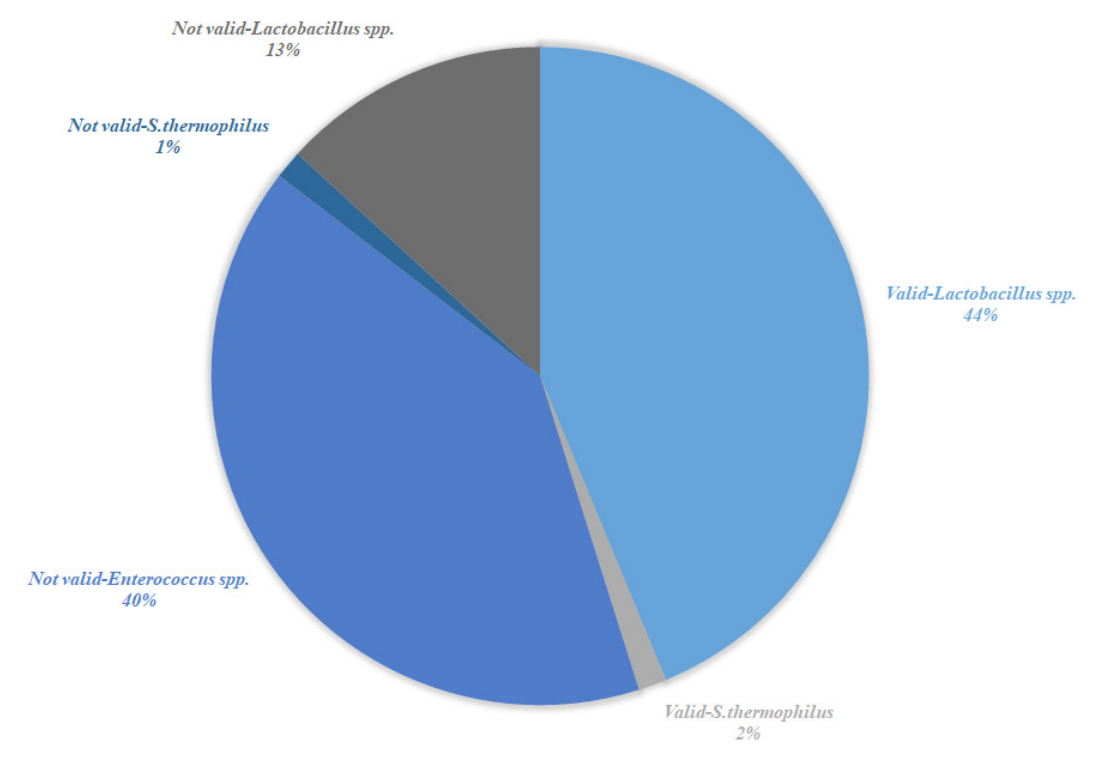

Figure 2. Validation of isolates as potential starter cultures 


\title{
Concluding remarks
}

144 lactic acid bacterial strains isolated from the artisanal Matsoni samples were evaluated from biotechnological point of view. 3 strains demonstrated an ability to produce bacteriocines, because of which they were excluded from the list of potential starters, but they can find other alternative uses, e.g as antimicrobial agents. The developed strain collection, counting 65 isolates, demonstrating valuable biotechnological properties, such as galactose fermentation, EPS production and casein degradation will undergo thorough molecular characterization, after which can be easily used for construction of the new Matsoni starters. A large body of information on diversity and metabolic activities of bacterial species isolated from artisanal Matsoni will allow to predict how to develop future regulatory requirements necessary to protect and preserve natural microbiota of artisanal products.

High frequency of occurrence of Enterococcus spp. in Matsoni samples suggests the importance of further investigation of their role in fermentation process and their role in development of the product taste. But as it was shown in previous study by Malkhazova et al. (2005) [8] a high percentage of Enterococcus isolates from Matsoni demonstrates an ability to decarboxylate tyrosine to tyramine, and may be associated with certain health hazards. Additionally, recent emergence of antibiotic resistance and virulent strains of Enterococcus spp. and their ability to horizontally transform resistance genes cause serious concerns on their use from food safety point. Therefore, the inclusion of Enterococcus species adding into the starter composition should be done with caution.

\author{
Элена Какабадзе ${ }^{1,2}$, Ната Бакурадзе ${ }^{1,2}$, \\ Нино Грдзелишвили ${ }^{2}$, Хатуна Макалатия ${ }^{1,2}$, \\ Гульнара Натрошвили ${ }^{2}$, Нина Чанишвили ${ }^{2}$ \\ ${ }^{1}$ Тбилисский государственный университет им. Иване Джавахишвили, \\ факультет точных и естественных наук, пр. Чавчавдзе, 1, 0179 Тбилиси, Грузия \\ ${ }^{2}$ Институт бактериофагии, микробиологии и вирусологии им. Г. Элиавы, \\ ул. Готуа, 3, 0160, Тбилиси, Грузия \\ тел.: +995322 374910 e-mail: elene.kakabadze@pha.ge
}

\section{МИКРОБИОЛОГИЧЕСКОЕ ИССЛЕДОВАНИЕ КАВКАЗСКОГО ПРОДУКТА МАЦОНИ}

\begin{abstract}
Реферат
Цель работы. Изучить микробный состав самодельных образиов мацони и выбрать бактериальные культуры для дальнейшего развития стандартизованного стартера. Методы. Выделение и очистка штаммов, оченка каталазной и уреазной активности культуры, оценка способности ферментации казеина, деградации галактозы, производство экзополисахаридов и бактериочинов, определение лизогенных итаммов. Результаты. Было выделено сто сорок четыре молочнокисльх бактериальных культур из 35 самодельных образиов Мацони, собранных из 24 различных поселений в Грузии в течение 2013-2014 г2. Бактериальная структура стартеров показала большое разнообразие в их составе, 3\% изолятов показали способность деградировать казеин и производить экзополисахариды, 32\% - ферментировать галактозу, 19\% проявили уреазную активность, 17\% - показали анта-
\end{abstract}


гонистическую активность и 14\% были обозначены как лизогены. Выводы. Разработанная коллекция штаммов имеет потенциал для обеспечения различных органолептических свойств конечным продуктам и, таким образом, может быть использована для новых стандартизированных стартеров Мацуони.

Ключевые слова: Lactic acid bacteria, Matsoni, Starter strain, Biotechnology.

\author{
Елена Какабадзе $\mathrm{e}^{1,2}$, Ната Бакурадзе $\mathrm{e}^{1,2}$, \\ Ніно Грдзелішвілі², Хатуна Макалатія ${ }^{1,2}$, \\ Гульнара Натрошвілі², Ніна Чанішвілі' \\ ${ }^{1}$ Тбіліський державний університет ім. Івана Джагашвілі,
} факультет точних і природничих наук, пр. Чавчавадзе, 1, 0179 Тбілісі, Грузія ${ }^{2}$ Інститут бактеріофагії, мікробіології і вірусології ім. Г. Еліаві, вул. Готуа, 3 0160, Тбілісі, Грузія

тел.: +995322 374910 e-mail: elene.kakabadze@pha.ge

\title{
МІКРОБІОЛОГІЧНЕ ДОСЛІЖЕННЯ КАВКАЗЬКОГО ПРОДУКТА МАЦОНІ
}

\begin{abstract}
Реферат
Мета. Вивчити мікробіний склад саморобних зразків Мацоні і вибрати бактеріальні культури для подальшого розвитку стандартизованого стартера. Методи. Виділення і очищення штамів, оцінка каталазної і уреазної активності культури, оцінка здатності ферментації казеїну, деградації галактози, синтез екзополіиукридів і бактеріоцинів, визначення лізогенних штамів. Результати. Було виділено сто сорок чотири молочнокислих бактеріальних культури з 35 саморобних зразків Мацоні, відібраних з 24 різних поселень в Грузї протягом 2013 - 2014 рр. Бактеріальна структура стартерів показала велику різноманітність в їх складі, 3\% ізолятів показали здатність деградувати казеїн і синтезувати екзополіиукриди, 32\% - ферментувати галактозу, 19\% виявили уреазну активність, 17\% - показали антагоністичну активність і 14\% були визначені як лізогени. Висновки. Розроблена колекиія штамів має потенціал для забезпечення різних органолептичних властивостей кінцевим продуктам і, таким чином, може бути використана для нових стандартизованих стартерів Мацоні.
\end{abstract}

Ключові слова: Lactic acid bacteria, Matsoni, Starter strain, Biotechnology.

\section{References}

1. Belguesmia Y., Choiset Y., Rabesona H., Baudy Floc'h M., Le Blay G., Haertlé T., Chobert J.M. Antifungal properties of durancins isolated from Enterococcus durans A5-11 and of its synthetic fragments // Lett. Appl. Microbiol. $-2013,-56(4),-$ P. 237-244.

2. Brussow H., Fremont M., Bruttin A., Sidoti J., Constable A., Fryder V. Detection and classification of Streptococcus thermophilus bacteriophages isolated from industrial milk fermentation // Appl. Environ. Microbiol. - 1994. - 60(12), -P. 4537-4543. 
3. Carminati D., Tidona F., Fornasari M.E., Rossetti L., Meucci A., Giraffa $G$. Biotyping of cultivable lactic acid bacteria isolated from donkey milk // Lett. Appl. Microbiol. - 2014. - 59(3), - P. 299-305.

4. De Man J.C., Rogosa D., Sharpe M.E. A medium for the cultivation of lactobacilli // J. Appl. Bacteriol. - 1960. - 23(1), - P. 130-135.

5. Hansen J.N., Sandine W.E. Nisin as a model food preservative // Crit. Rev. Food Sci. Nutr. - 1994. - 34(1), - P. 69-93.

6. Heller K.J. Probiotic bacteria in fermented foods: product characteristics and starter organisms // Am. J. Clin. Nut. - 2001. - 73(2), - P. 374s-379s.

7. Kinová S.H., Bilkova A., Bukovský M. Lactobacilli and their probiotic properties//LC-GC Czech Pharm. Soc. Slovak Pharm. - 2008. - 57(2), - P. 95-98.

8. Malkhazova Y., Chanishishvili N., Aleksidze N., Parente E. Technological and biochemical properties of enterococci isolated from lactic acid products// NTZ Bull. Acad. Agric. Sci. -2005 -0869-3730 N1. - P. 66-69.

9. Michaylova M., Minkova S., Kimura K., Sasaki T., Isawa K. Isolation and characterization of Lactobacillus delbrueckii ssp. bulgaricus and Streptococcus thermophilus from plants in Bulgaria // FEMS Microbiol. Lett. - 2007. - 269(1), -P. 160-169.

10. Mora D., Fortina M. G., Parini C., Ricci G., Gatti M., Giraffa G., Manachini P. L. Genetic diversity and technological properties of Streptococcus thermophilus strains isolated from dairy products // J. Appl. Microbiol. - 2002. 93(2), - P. 278-287.

11. Quero G. M., Fusco V., Cocconcelli P. S., Owczarek L., Borcakli M., Fontana C., Morea M. Microbiological, physico-chemical, nutritional and sensory characterization of traditional Matsoni: selection and use of autochthonous multiple strain cultures to extend its shelf-life // Food microbiol. -2014. - 38, - P. 179-191.

12. Ra'l R. R., H'bert, E. M. Isolation of phage via induction of lysogensGuelph, Canada: Humana Press, 2009. 23-32 p.

13. Ruas-Madiedo P., De Los Reyes-Gavilán C.G. Invited review: methods for the screening, isolation, and characterization of exopolysaccharides produced by lactic acid bacteria // J. Dairy Sci. - 2005. - 88(3), - P. 843-856.

14. Turner K.W., Martley F.G. Galactose fermentation and classification of thermophilic lactobacilli // Appl. Environ. Microbiol. -1983. - 45(6), - P. 19321934.

15.http://www.sakpatenti.org.ge/index.php?lang_id=ENG\&sec_ $\mathrm{id}=325 \&$ lang_id=GEO. 18 July 2018

This study was performed with support of following grant programs:

CRDF - A 60792

SRNSF- DO/311/7-280/14

There is no conflict of interest between the authors

Стаття надійшла до редакції 28.01.2018 р. 